\title{
Isotopic Effects of Tritium during the Growth of White Willow ${ }^{i}$
}

\author{
Viktor V. Dolin*, Vasyl M. Bobkov, Oleksandr V. Pushkarev, Tetiana O. Koshliakova \\ Institute of Environmental Geochemistry, Ukraine
}

Copyright $\mathrm{C} 2018$ by authors, all rights reserved. Authors agree that this article remains permanently open access under the terms of the Creative Commons Attribution License 4.0 International License

\begin{abstract}
In a greenhouse experiment, some features of Tritium migration from an aqueous feeding solution to white willow (Salix alba L.) habitat components and isotopic effects of hydrogen during the willow growth have been studied. A number of rate constants for tritiated water diffusion through pores, cell membranes and uptake through the root system $\left(\mathrm{k}=(8.44 \pm 0.03) \cdot 10^{-7} \mathrm{~s}^{-1}\right) ;{ }^{3} \mathrm{H} /{ }^{1} \mathrm{H}$ isotopic exchange in $\mathrm{OH}$ - groups of organic substances $(\mathrm{k}$ $\left.=5.07 \cdot 10^{-7}\right)$; "isotopic lightening" during photosynthesis $\left(\mathrm{k}=5.00 \cdot 10^{-8}\right)$ were calculated from the experimental data. The rate constant of tritium transfer through the root system to intercellular sap of plants is $2.17 \pm 1.45 \cdot 10^{-6} \mathrm{~s}^{-1}$. The tritium distribution between the feeding solution and the intercellular sap has come to equilibrium within 1-2 weeks. The fractionation factor $(\alpha)$ is $0.88-0.94$ and does not depend on the concentration of ${ }^{3} \mathrm{H}$ in the feeding solution. The rate constant of transformation of tritium into organically bound species is $8.6 \pm 3.0 \cdot 10^{-7} \mathrm{~s}^{-1}$. The equilibrium has set from 4 to 11 weeks, $\alpha=0.17-0.19$ and does not depend on ${ }^{3} \mathrm{H}$ concentration in the feeding solution. At the same time, strong isotopic effect of "lightening" of the feeding solution, probably owing to transpiration, has been observed. The rate constant value of Tritium transpiration calculated from the experimental data is $2.67 \pm 0.27 \cdot 10^{-8} \mathrm{~s}^{-1}$. The rate of tritium removal due to transpiration is proportional to its concentration in the feeding solution. The factor of tritium fractionation during transpiration is $1.35 \pm 0.08$.
\end{abstract}

Keywords Tritiated Water, Willow, Intercellular Sap, Organically Bounded Tritium, Rate Constant

\section{Introduction}

Numerous studies conducted in the affected area of radioactive waste storage facilities showed that Tritium accumulates in various tree tissues in significant quantities [1-6].
In living wood, tritium is concentrated in free water which is a part of plant intercellular sap (in the form of tritiated water $\mathrm{H}-\mathrm{O}-\mathrm{T}$ ), and in organic matter of plants (cellulose, lignin etc.) by replacement of protons of $\equiv \mathrm{CH}$ and $\equiv \mathrm{COH}$ groups for tritium. The prior measurements established the fact that Tritium content in the wood increases as a result of the elevated Tritium concentration in the external environment. But the available data were insufficient to study the dynamics of this process. The rate and features of Tritium accumulation in natural plants within the area adjacent to radioactive waste storage facilities and nuclear power plants were not evaluated clearly because of the multifactor powerful and uncontrolled influence of the atmospheric precipitates, groundwater, solar radiation and winds.

The difference between Tritium and Protium masses caused fractionation in chemical and physical processes. This leads to enrichment with a heavy isotope of one fraction in contrast to another fraction. This effect is most prominent in phase changes of chemical compounds which contain hydrogen isotopes and, above all, during water evaporation. The difference between the masses of $\mathrm{H}_{2} \mathrm{O}$ and HTO molecules is not significant:

$$
\frac{m_{\mathrm{H}_{2} \mathrm{O}}}{m_{\mathrm{HTO}}}=0.9
$$

Despite this fact, the equilibrium distribution of ${ }^{3} \mathrm{H}$ between aqueous and gaseous water phases differs from the uniform. This distribution depends on temperature and the difference in vapor pressure between Tritium and Protium waters.

According to $[7,8]$, the factor of tritium distribution between tritiated water and its vapor can be calculated from the equation:

$$
\alpha=\frac{P_{H}^{0}}{P_{T}^{0}}
$$

where $\alpha$ is the distribution factor, $P_{H}^{0}$ is the vapor pressure of Protium water at a given temperature, $P_{T}^{0}$ is 
the vapor pressure of Tritium water in pure form at the same temperature. A similar regularity is also valid for deuterium water and heavy-oxygen water. So, evidently, during transpiration, leaf water enrichment in heavy isotopes can occur. This effect has been shown for the ${ }^{18} \mathrm{O} /{ }^{16} \mathrm{O}$ ratio that increases in leaf and needle water in daytime from 9 am to $3 \mathrm{pm}$ [9]. At night the value of this ratio decreases owing to interrelation between intensity of fractionation and transpiration. However, the value of oxygen isotope ratio did not change in the water of branches, roots, soil and air.

Dependence of ${ }^{18} \mathrm{O}$ content in organic matter of young leaves of wood plants on transpiration water loss is described in the research work [10]. During the experimental observation of transpiration processes, influence (in tritium-containing atmosphere) on tritium fractionation in plants (wheat, corn) and effect of isotopic fractionation in transpiration from plant leaves was revealed [11].

To study the time-dependent regularities of Tritium interaction between inanimate and living matter, we conducted active (greenhouse) experiments, which allowed to estimate the rate of Tritium accumulation in wood under controlled conditions.

The aim of this work was to estimate the rate and the extent of tritium migration in the system: external aquatic environment (feeding solution) - intercellular sap organically bound Tritium.

\section{Materials and Methods}

The objects of the research were tritiated water with initial activity $\mathrm{C}_{\text {init. }} \approx 5600 \mathrm{~Bq} \cdot \mathrm{dm}^{-3}$ and $2800 \mathrm{~Bq} \cdot \mathrm{dm}^{-3}$ (feeding solution), and willow planting stock (Salix alba L.). To assess the concentration effects, we used two 70 $\mathrm{dm}^{3}$ containers filled with water of different initial Tritium activity. A $5 \mathrm{~cm}$ layer of dried peaty soil was placed into each container. 16 willow saplings were planted in the container No 1 and 25 willow saplings in the container No 2. The experiment was set up in normal conditions (NTP: as air at $20^{\circ} \mathrm{C}$ and $1 \mathrm{~atm}$.)

During the experiment, we observed significant transpiration of water throw the willow leaves. Twenty weeks after the beginning of the experiment 5 willow saplings remained in the container No 2. Soil layer in this container was still damp, but free water completely vanished. $66 \mathrm{dm}^{3}$ of light water with Tritium activity of 7 $\mathrm{Bq} \cdot \mathrm{dm}^{-3}$ was poured into this container. Sampling and measurements during next 5 weeks were done as described below.

In comparison with water plants, the willow has significant advantages. It grows well in water in the laboratory conditions and gains weight rapidly, which allows obtaining quantum satis of the counting form after incineration. Willow feels good under artificial lighting in greenhouse conditions for a long time.
Much larger volume of tritiated water than required for plants nutrition was added to the containers. Balance distribution and the quantity of tritium included into biogeochemical processes during the experiment were determined with the respect to tritium concentration in this aqueous feeding solution.

\subsection{Experimental Technique}

Suitable willow cuttings (with the weight of 70-140 g and the length of 50-65 cm) were cut from healthy willow branches during the growing season. The cuttings were soaked in heteroauxin solution for 24 hours and planted in the ground outdoors. For three weeks the cuttings sprouted and covered with leaves. Then they were dug up carefully and transferred to rectangular plastic $70 \mathrm{dm}^{3}$ containers (№ 1 and 2) (Fig. 1).

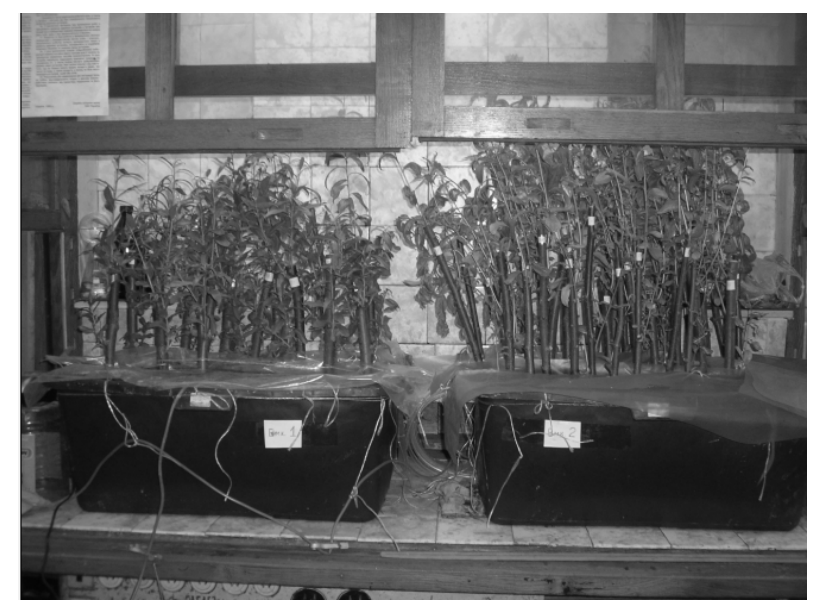

Figure 1. Experimental set up

As is well known, the main ways of water transfer into the plants are assimilation of vapor phase through the leaves and aqueous phase through the roots. Therefore for the purity of the experiment, entire volume of the tritiated water was collected in the appropriate container where willow planting stock was growing. The container was covered with a polyethylene film in such a way that the tritiated water could transfer into the plants only through the roots, pores and cell membranes of the willow. The leaves isolated by the film absorbed only background atmospheric moisture.

\subsection{Feeding Solution and Intercellular Sap}

Once a week we sampled aqueous feeding solution and willow saplings. Roots with soil were removed and the trunk was dried with a filter paper. After weighing, a sapling with young branches and leaves was cut into small pieces $(5-6 \mathrm{~cm})$ and transferred to a $1 \mathrm{dm}^{3}$ glass container. A beaker with $50 \mathrm{~g}$ of roasted calcium chloride was placed into this container. The container was covered with a Petri dish and kept in a drying box at the temperature of $90^{\circ} \mathrm{C}$ for 
24 hours. Calcium chloride, saturated with water, was taken to the Wurtz flask, and the absorbed water was driven off by heating and collected to a vial.

\subsection{Organically Bound Tritium (OBT)}

The semi-dry vegetation has been dried for one more day to a constant weight at the temperature of $100^{\circ} \mathrm{C}$. The solid residue was weighed, transferred to a quartz tube and burned down carefully in an oxygen stream utilizing $\mathrm{CuO}$ catalyzer (Fig 2). Water vapor was condensed in a cooling table. When the water sample was contaminated with combustion products, it was rectified repeatedly with addition of an inorganic hydrogen-free oxidizer $\left(\mathrm{KMnO}_{4}\right.$, $\mathrm{K}_{2} \mathrm{Cr}_{2} \mathrm{O}_{7}$ ) for complete oxidation of the organic dash.

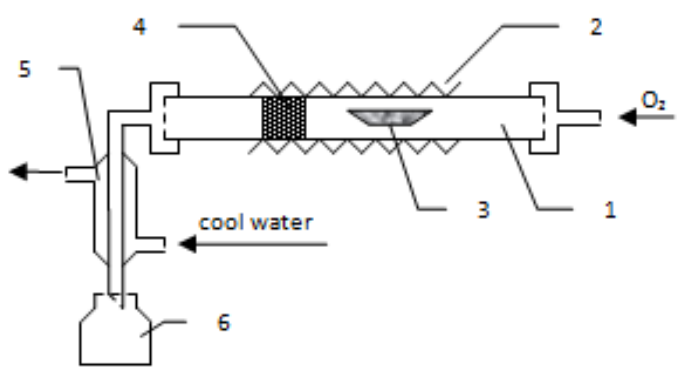

1 -Quartz tube; 2 - Tube furnace; 3 - Sample; 4 - CuO katalyzer, 5 - Cooling table; 6 - Vial (glass for liquid sample)

Figure 2. Device for OBT analysis

\subsection{Measurements}

All water samples including the feeding solution from both containers were rectified with the addition of the oxidizer. A counting form was prepared on the basis of the refined water samples: special polyethylene $20 \mathrm{~cm}^{3}$ vial was filled with $8 \mathrm{~g}$ of the analyzed rectified water. If the sample quantity was insufficient $(<8 \mathrm{~g})$, the lacking amount of distilled water with known Tritium content was added to the test sample, so the total amount of the aqueous phase in the vial was $8 \mathrm{~g}$. Then $12 \mathrm{~g}$ of scintillation liquid Perkin Elmer OPTIPHASE HiSafe 3 was added to the vial. The sample was mixed thoroughly. Tritium activity was measured using a liquid-scintillation $\alpha-\beta$-spectrometer Quantulus 1220. Inaccuracy of measurements did not exceed $5 \%$.

\section{Results and Discussion}

\subsection{The Rate of Tritium Biogenic Flux during Willow Growth in Tritiated Water}

During 5 months, the Tritium concentration in the aqueous feeding solution was significantly decreased (upper curve in Fig. 3 A, B). This effect cannot be caused by evaporation, because normally during evaporation the concentration of heavy isotope increases in aqueous phase [12]. Biogenic removing of the heavy isotope from the system is likely the result of transpiration, i.e. water evaporation from the surface of plants through the cuticle.

So, the steady trend of Tritium activity decreasing in the feeding solution (tritium concentration decreased by $20-30 \%$ within $4-5$ months) that we observed, is the evidence of the extraordinary power of the isotopic evapotranspiration effect during willow growing in the tritiated water (Fig. 3). This type of vegetation can be compared to a powerful pump, which pumps Tritium to the atmosphere from the water-marsh ecosystem.

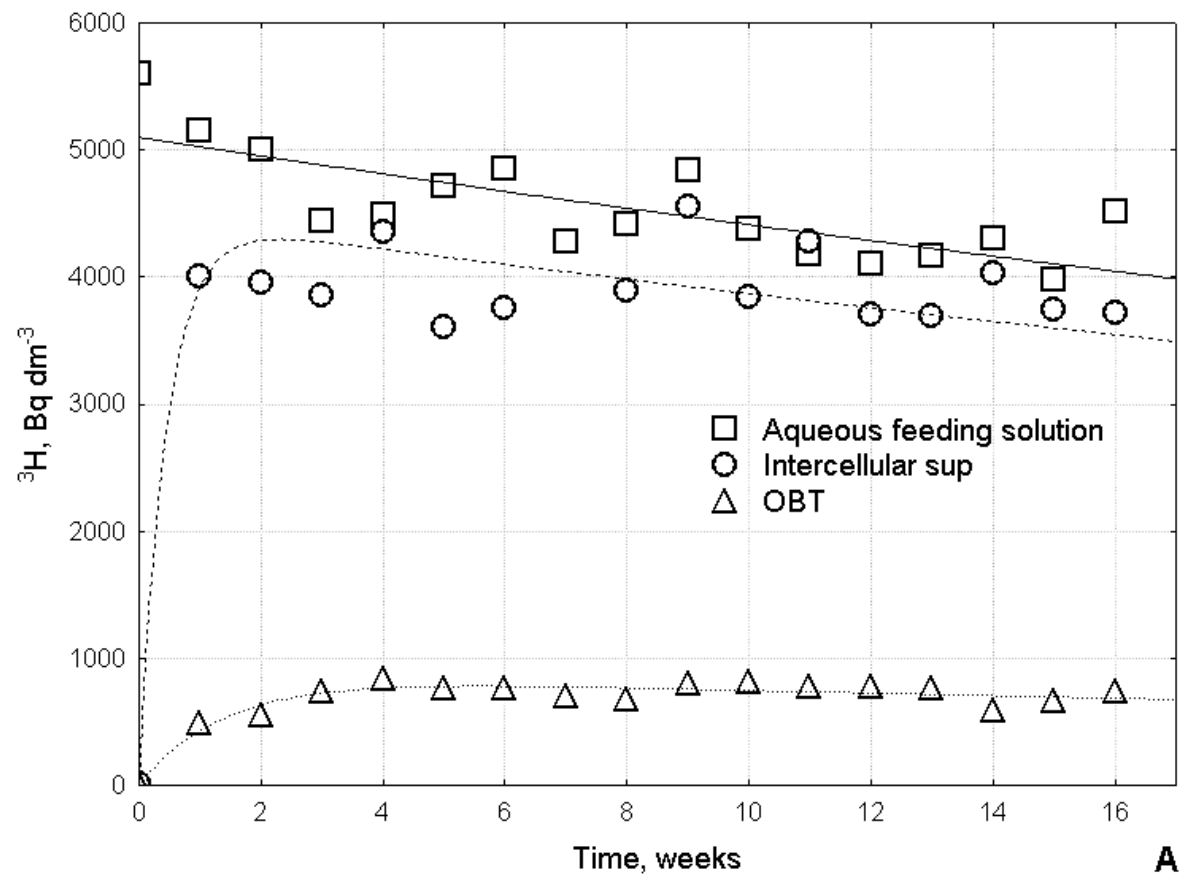




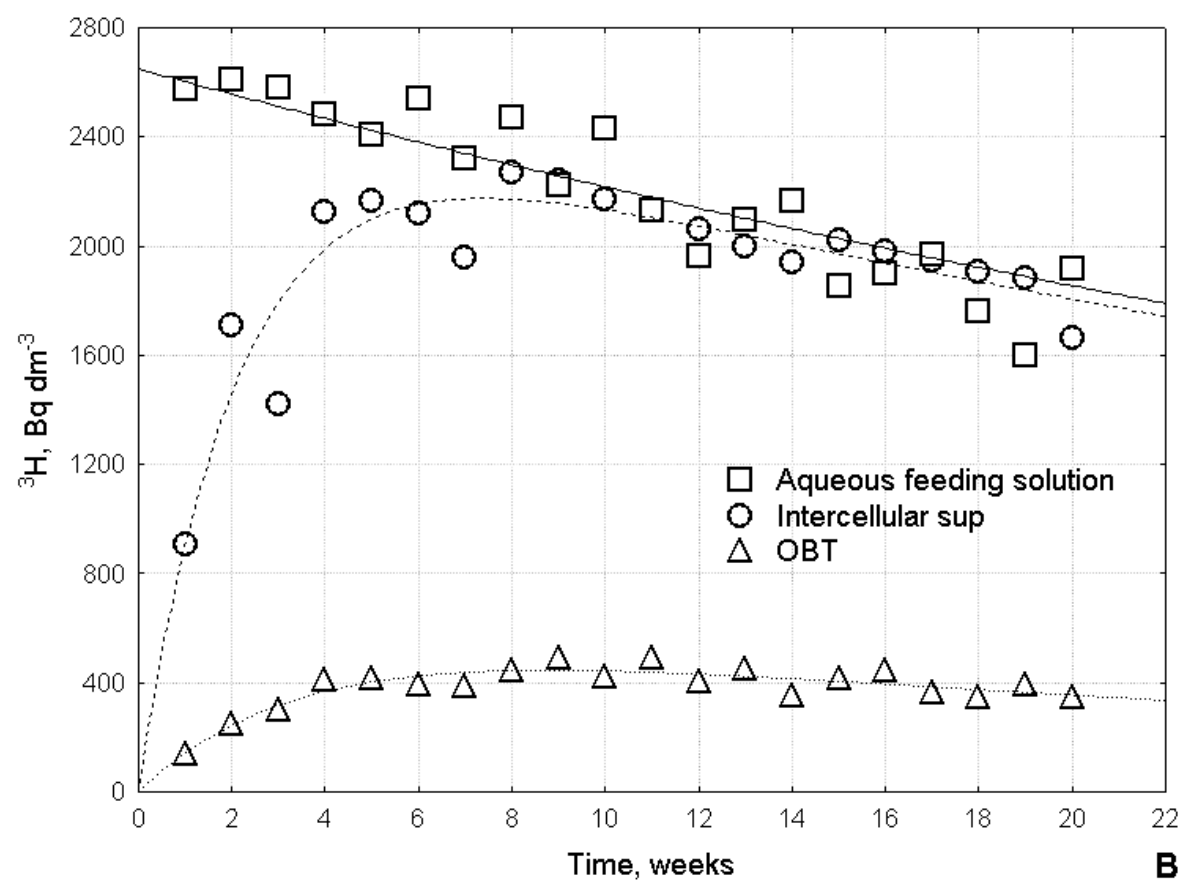

Figure 3. Tritium redistribution between biotic and abiotic components during the experiment: A - container № 1, B - container № 2 .

The velocity of this process is estimated by tritium concentration decreasing in external water:

$$
C_{t}=A_{1} \times e^{-k_{1} t}
$$

where $A_{l}$ is the initial water activity, $C_{t}$ is the Tritium concentration in the feeding solution at time $t$, and $k_{l}$ corresponds to the rate constant of biogenic evapotranspiration tritium flow. The value of $k_{1}$, calculated from the experimental data, is amounted to $(2.4-2.94) \cdot 10^{-8} \mathrm{~s}^{-1}$ (Table 1).

Table 1. The rate constants of tritium biogenic flux during willow growth in tritiated water

\begin{tabular}{|c|c|c|c|}
\hline \multirow{2}{*}{ Parameter } & \multicolumn{2}{|c|}{ Container number } & \multirow{2}{*}{ Mean value } \\
\cline { 2 - 3 } & 1 & 2 & \\
\hline$A_{1}, \mathrm{~Bq}$ & 5099 & 2757 & N/A \\
\hline$k_{1}, \mathrm{~s}^{-1}$ & $2.40 \cdot 10^{-8}$ & $2.94 \cdot 10^{-8}$ & $2.67 \cdot 10^{-8}$ \\
\hline$A_{2}, \mathrm{~Bq}$ & 4473 & 2581 & $\mathrm{~N} / \mathrm{A}$ \\
\hline$k_{2}, \mathrm{~s}^{-1}$ & $3.62 \cdot 10^{-6}$ & $7.27 \cdot 10^{-7}$ & $2.17 \cdot 10^{-6}$ \\
\hline$A_{3}, \mathrm{~Bq}$ & 864 & 535 & $\mathrm{~N} / \mathrm{A}$ \\
\hline$k_{3}, \mathrm{~s}^{-1}$ & $1.16 \cdot 10^{-6}$ & $5.64 \cdot 10^{-7}$ & $8.61 \cdot 10^{-7}$ \\
\hline$A_{2}, \%$ & 88 & 94 & 91 \\
\hline$\underline{A_{3}}, \%$ & 17 & 19 & 18 \\
\hline
\end{tabular}

Note: N/A - not applicable.

During 5 months of the experiment, biogenic flow has removed about 62 liters $(94 \%)$ of water from the system. The specific rate of water removal owing to transpiration amounts to $3.8 \cdot 10^{-4} \mathrm{~cm}^{3} \cdot \mathrm{s}^{-1}$ (about $10 \mathrm{dm}^{3}$ per month) per 1 $\mathrm{kg}$ of the willow biomass. At that, Tritium volume removal during 1 week is more than four times higher than its content in the intercellular water of the willow. The average specific rate of tritium removal by biogenic flow is proportional to its content in the feeding solution. When the initial Tritium concentration in the aqueous feeding solution was $2800 \mathrm{~Bq} \cdot \mathrm{dm}^{-3}$ the specific rate of transpiration flow per $1 \mathrm{~kg}$ of the willow biomass was $8.0 \cdot 10^{-6} \mathrm{~Bq} \cdot \mathrm{s}^{-1}$ (21 Bq per month), while for the concentration of $5600 \mathrm{~Bq} \cdot \mathrm{dm}^{-3}$ it is equal to $1.7 \cdot 10^{-5} \mathrm{~Bq} \cdot \mathrm{s}^{-1}$ (44 Bq per month).

During transpiration, we have observed tritium fractionation with coefficients $(\alpha)$ of 1.43 (for 20 weeks in container No 2) and 1.26 (for 16 weeks in container No 1), respectively:

$$
\alpha=\frac{C_{t_{1}}}{C_{t_{2}}}
$$

In previous studies [6], we observed isotopic effects relative to accumulation of the superheavy isotope in intercellular sap and organically bound species of water-marsh plants. In the greenhouse experiment of willow growing in tritiated water such a clear effect was not observed. Tritium fractionation factor between environmental water and intercellular sap $(\alpha)$ was equal to 0.88-0.94 and practically did not depend on the concentration of the superheavy hydrogen isotope in external water. Factor of Tritium fractionation into organically bound species of the willow biomass was between 0.17 and 0.19 and also did not depend on the concentration of the superheavy hydrogen isotope in external water.

The dynamics of Tritium biogenic migration in the aqueous form and its transformation into organic compounds with high reliability is described from the point 
of formal kinetics for irreversible process:

$$
C=A_{2,3} \times e^{-k_{1} t} \times\left(1-e^{-k_{2,3} t}\right)
$$

where $A_{2,3}$ - the amount of tritium that is involved in migration to inorganic (intercellular aqueous) form $\left(A_{2}\right)$ and to organically bound species $\left(A_{3}\right), k_{2,3}$ - rate constants of corresponding transformations; $k_{l}$ - rate constant of tritium removal from the system as a result of transpiration, calculated from the experimental data using the equation 2 (Figure 3, Table 1).

Calculated values of rate constants for tritium involved into biogenic migration differ significantly (up to 2 times), depending on the initial concentration of the isotope in the system (Table 1). The tendency of Tritium biogenic migration rate increase according to increasing of its entire amount in the system is observed. In relation to activity of the feeding solution, average portion of Tritium accumulated in intercellular sap of the willow is $91 \%$, and that transferred to organically bound species is $18 \%$.

\subsection{The Rate of ${ }^{3} \mathrm{H}-{ }^{1} \mathrm{H}$ Isotopic Exchange in Willow Biogeosystem}

Since tritiated water was removed with biogenic flux, the light Protium water with Tritium concentration of 7 $\mathrm{Bq} \cdot \mathrm{dm}^{3}$ was poured to the container No 2 with the remaining 5 willow saplings. In the sequel, saplings were sampled weekly. During next 5 weeks we observed decrease of Tritium content both in the intercellular sap and organically bound species. Tritium extraction from the peaty soil layer resulted in the increase of aqueous feeding solution activity (Figure 4).

Comparison of Tritium dynamics in the willow tissues during its growth in tritiated water ("direct experiment") and later in Protium water ("reverse experiment") during every first 5 weeks of the experimental study allowed us to assess the kinetic rate constant for Tritium-Protium exchange between the aqueous feeding solution, intercellular sap and organically bound species. We consider these transformations from the position of formal kinetics for the irreversible process in active experiment, when the researcher sets up the direction of the process. According to this approach, the chemical reaction rate changes due to attenuation of the starting substances (A) and accumulation of the reaction products (B) of the chemical reaction by exponential law:

$$
C_{A}=a e^{-\vec{k} t}
$$

and

$$
C_{B}=b\left(1-e^{-\bar{k} t}\right)
$$

where $\vec{k}$ and $\overleftarrow{k}$ are rate constants of symmetric processes of direct (A) and reverse (B) reactions (Figure 5).

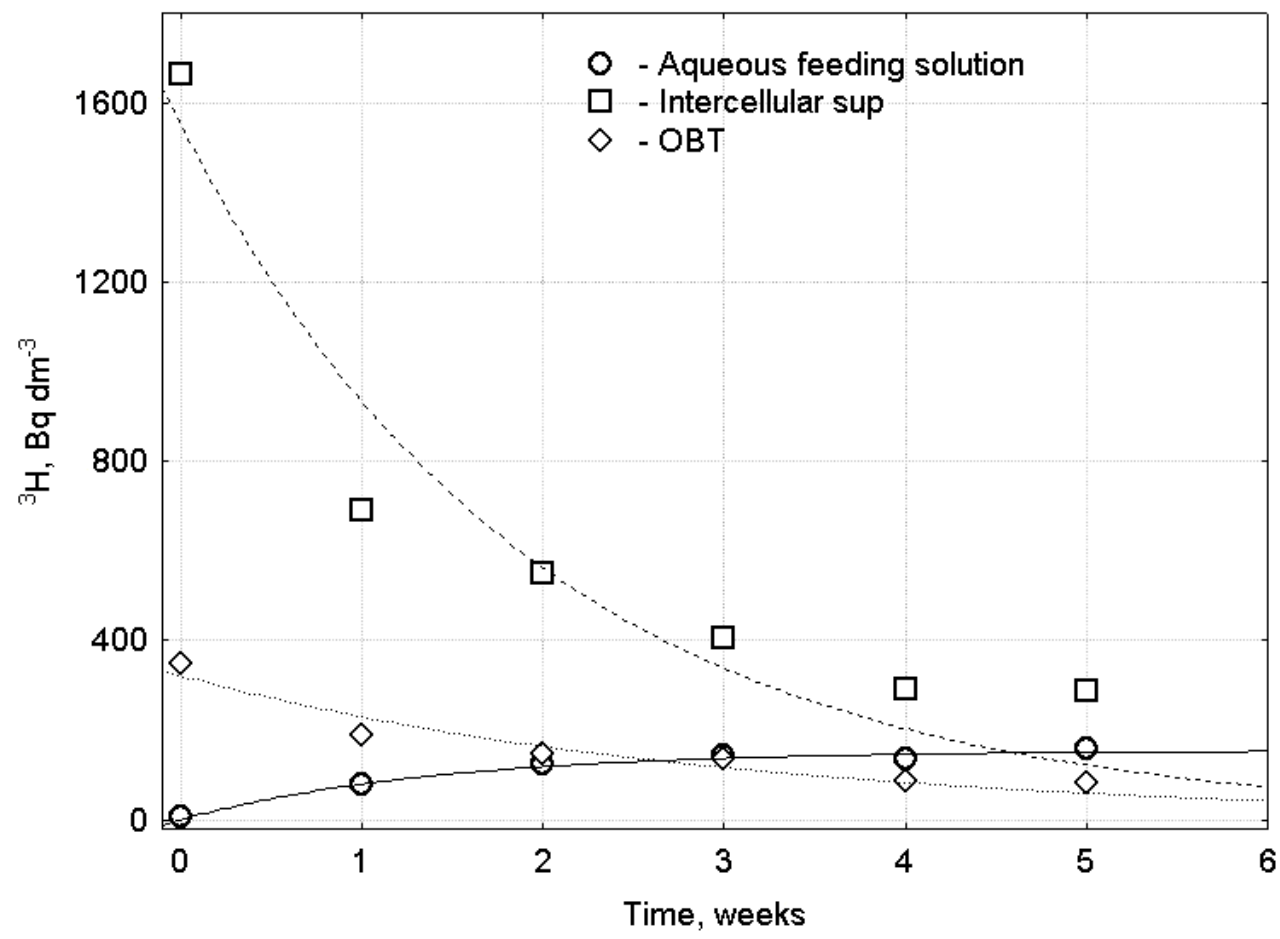

Figure 4. Tritium distribution in willow tissues during vegetation in light water (reverse experiment) 


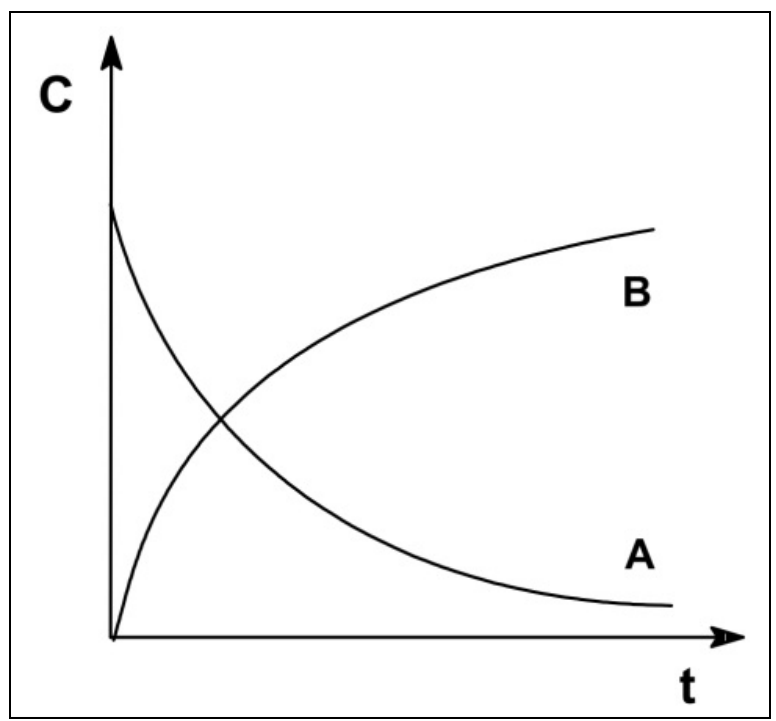

Figure 5. Kinetic curves for starting substances (A) and reaction products (B) of chemical reaction [13].

The kinetic rate constants calculated from the experimental data for direct and reverse Protium-Tritium exchange between the aqueous feeding solution and intercellular sap of the willow (Figure 6) are in good agreement:

$$
\vec{k} \cong \overleftarrow{k}=(8.44 \pm 0.03) \cdot 10^{-7} s^{-1}
$$

So, the rates of direct and reverse diffusion of tritiated water through pores, cell membranes and uptake through the root system of the willow are the same.

Tritium incorporation into organically bound species occurs due to isotopic exchange of Protium for Tritium in organic matter of living organisms. Plants organic matter consists mainly from polymer cellulose that in turn consists from D-glucose links (Figure 7 A) [14]. Tritium may replace 10 atoms of Protium: 3 of them are bonded to Oxygen, and 7 atoms are bonded to Carbon. The cell membrane of some species of water plants (e.g. kelp) is built predominantly from polysaccharide alginic acid. The alginic acid link contains 3 hydroxyl and 5 alkyl protons (Figure 7 B). Agile Hydrogen from the hydroxyl groups easily exchange for Tritium in the tritiated intercellular sap media which washes the plant tissues. Alternatively, isotopic exchange of alkyl protons for Tritium is significantly slower [15].

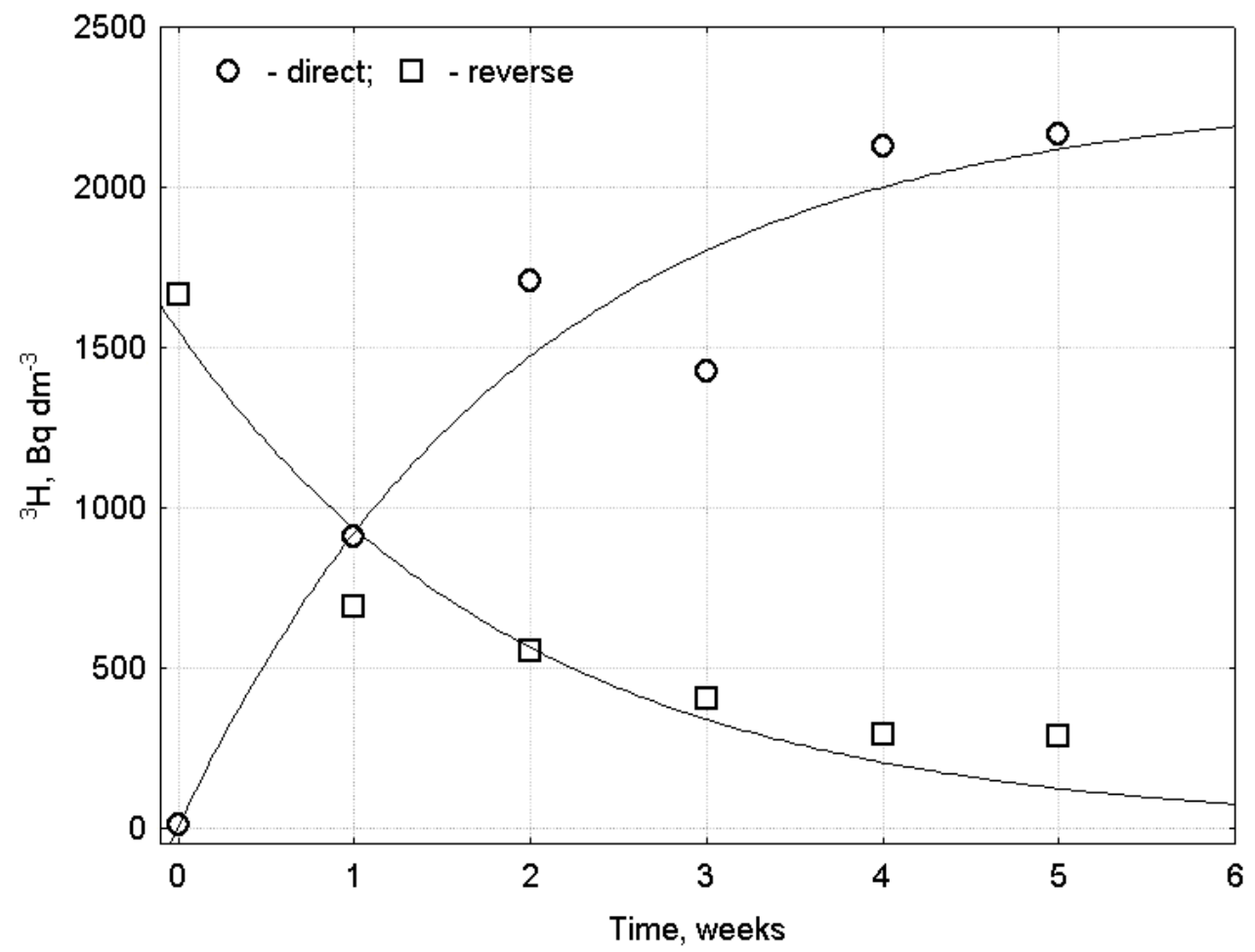

Figure 6. Dynamics of Tritium accumulation (direct experiment) and attenuation (reverse experiment) in willow intercellular sap 


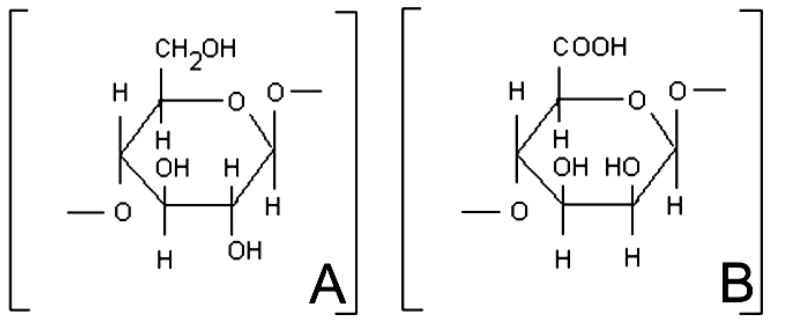

Figure 7. Links of plants organic matter: D-glucose (A) and alginic acid (B).

Besides isotopic exchange, Tritium incorporation into organic matter occurs in photosynthesis. During the biological evolution, the mechanism of assimilation, predominantly, of a light isotope has been created because it is energetically favorable. Fixation of $\mathrm{CO}_{2}$ and $\mathrm{H}_{2} \mathrm{O}$ in organic matter leads to depletion of plants in Deuterium in relation to water $[16,17]$. Therefore in our "direct" experiment, isotopic exchange of Protium for Tritium in -O-H groups of plant organic matter occurs in opposite direction to isotope fractionation in $\equiv \mathrm{C}-\mathrm{H}$ groups owing to photosynthesis. In the "reverse" experiment, these processes are of the same direction. The kinetic rate constants for organically bound Tritium calculated from the experimental data (Figure 8) are:

$$
\vec{k}=4.58 \cdot 10^{-7} s^{-1} \text { and } \overleftarrow{k}=5.57 \cdot 10^{-7} s^{-1}
$$

The difference between these rate constants allows calculating the rate of ${ }^{1} \mathrm{H} /{ }^{3} \mathrm{H}$ fractionation in photosynthesis $\left(k_{P h}\right)$ :

$$
k_{P h}=(\overleftarrow{k}-\vec{k}) / 2=5.00 \cdot 10^{-8} s^{-1}
$$

Available data on tritium accumulation in plant tissues after an accidental release from nuclear facilities are varied and contradictory. Researchers from Belgium (Mol) after a radiation accident observed that in aqueous ecosystem Tritium incorporation into organic matter of plants, fish and eggs (duck) is higher than into river water by a factor of 20 [3]. Our research within the affected zone of Kyiv radioactive waste facility (Ukraine) showed enrichment of marsh plant intercellular sap and organic matter with Tritium by a factor from 1.1 to 8.1 [6]. These observations were in conflict with the results from the experiments in laboratory aquaria in which Tritium was present as HTO [3].

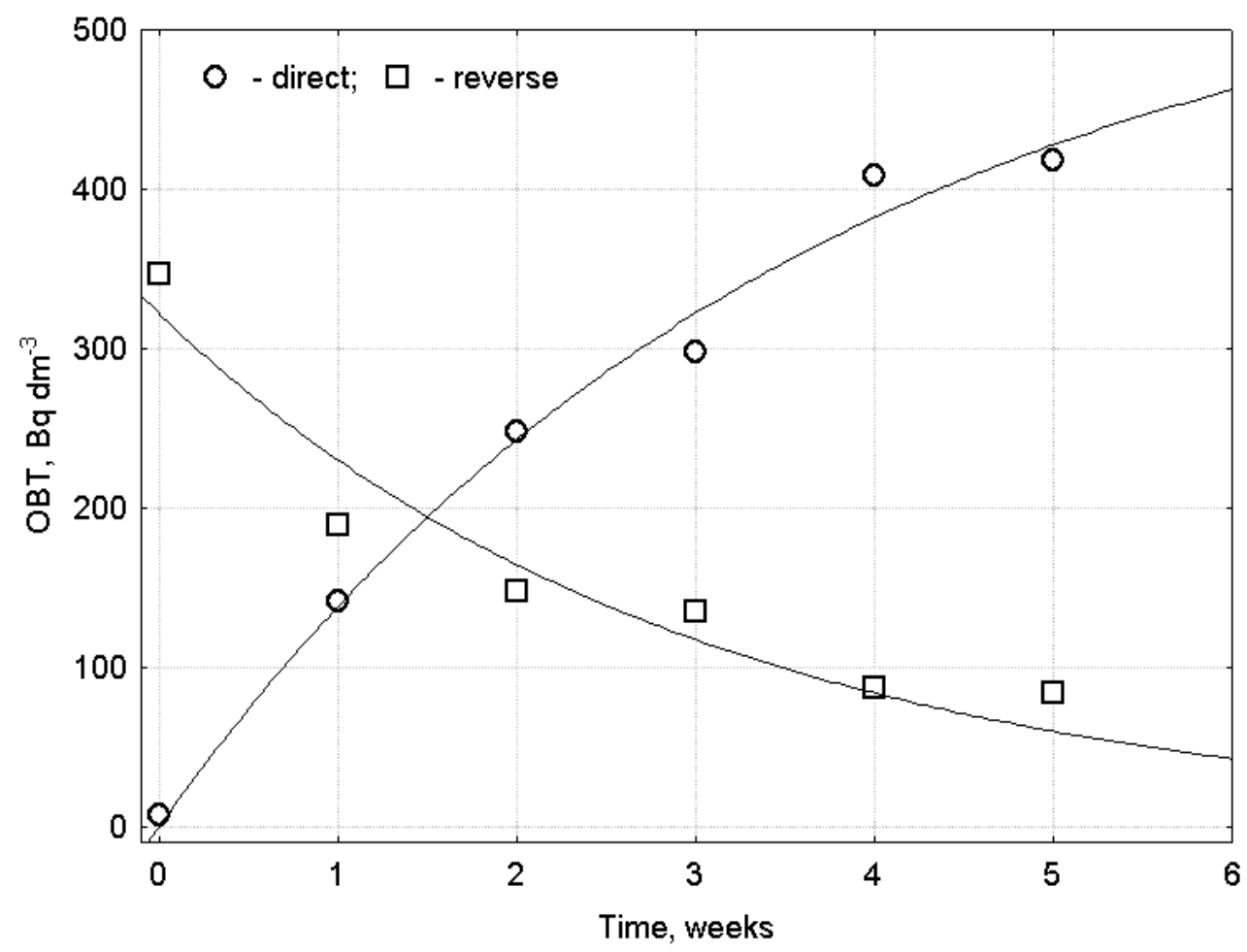

Figure 8. Dynamics of Tritium accumulation (direct experiment) and attenuation (reverse experiment) in organically bounded species. 
The difference of the rate constants of Tritium isotopic exchange between plant tissues and aqueous feeding solution presented in this paper could explain these contradictions. The most intensive process is isotopic exchange in external aqueous media: the rate constant evaluated in [18] is $2-3$ orders of magnitude higher than "biogenic assimilation" of Tritium and isotopic exchange in organic substances of living matter (Table 2). Therefore, after "fast" decontamination of external aqueous media (feeding solution) from accidental Tritium release, one can observe "pseudo-accumulation" of Tritium in plants due to "slow" decontamination of intercellular sap and organic substances in living matter.

Table 2. Rates of Tritium-Protium interaction in willow biogeosystem

\begin{tabular}{|l|c|}
\hline \multicolumn{1}{|c|}{ Type of the process } & Rate constant, $\mathrm{s}^{-1}$ \\
\hline $\begin{array}{l}\text { Isotopic exchange within inanimate aqueous } \\
\text { medium [18] }\end{array}$ & $(1-2) \cdot 10^{-4}$ \\
\hline $\begin{array}{l}\text { Diffusion of tritiated water through pores, cell } \\
\text { membranes and owing to root nutrition }\end{array}$ & $(8.44 \pm 0.03) \cdot 10^{-7}$ \\
\hline $\begin{array}{l}\text { Isotopic exchange in HO- groups of organic } \\
\text { substances in living matter }\end{array}$ & $5.07 \cdot 10^{-7}$ \\
\hline $\begin{array}{l}\text { "Isotopic lightening" in } \mathrm{HC} \equiv \text { groups during } \\
\text { photosynthesis }\end{array}$ & $5.00 \cdot 10^{-8}$ \\
\hline
\end{tabular}

\section{Conclusions}

During vital activity of a willow in a greenhouse experiment, powerful transpiration effect accompanied by fractionation of the superheavy hydrogen isotope has been observed. The specific rate of biogenic water flow in the system is equal to $3.8 \cdot 10^{-4} \mathrm{~cm}^{3} \cdot \mathrm{s}^{-1}$ per $1 \mathrm{~kg}$ of the plant biomass. The rate of tritium removal as a result of transpiration is proportional to its initial concentration in the feeding solution. The value of biogenic flow transfer of the superheavy isotope from the tritiated water medium to the atmosphere during one week is four times higher than Tritium content in the plant intercellular sap. The Tritium fractionation factor in transpiration process is equal to 1.35. White willow can be used as a pump for phytoremediation of cooling ponds of nuclear facilities from Tritium (Patent UA $112471 \mathrm{U}$ ).

The processes of contamination and decontamination of aqueous and organic phase of plant tissues with Tritium are symmetrically reversible and subject to a kinetic mechanism. The rate constant of tritium contamination of plant intercellular sap, on average, is twice as high as the rate constant for its transformation to organically bound species. The rate constant of Hydrogen "isotopic lightening" during photosynthesis is evaluated as $5.00 \cdot 10^{-8} \mathrm{~s}^{-1}$.

Enrichment of inorganic and organic biotic components with Tritium has not been observed in the experimental conditions. ${ }^{3} \mathrm{H} /{ }^{1} \mathrm{H}$ fractionation factor for the intercellular sap calculated relative to the aqueous feeding solution is $0.87-0.94$ and for organically bound species it is $0.17-0.19$.
The variability in published data on Tritium accumulation in organic matter of living organisms after accidental release of tritiated water into environment may be explained by the difference between ${ }^{3} \mathrm{H} /{ }^{1} \mathrm{H}$ isotopic exchange rates in water, $\mathrm{OH}-$ and $\mathrm{CH} \equiv$ groups of living organic matter, diffusion of tritiated water through pores, cell membranes and root system.

\section{Acknowledgements}

This paper is dedicated to $100^{\text {th }}$ anniversary of National Academy of Sciences of Ukraine, which funded this research (Contract No III-04-16 "Environmental Security of Artificial Hydrogen Isotopes"). Special thanks to Natalia Mitsiuk for editing and correction.

\section{REFERENCES}

[1] Y. Belot, C. Caput, D. Gauthier. Distribution of the organically bound tritium in vegetation exposed to fall-out, Radiat. Protect. Dosim, Vol. 16, No 1-2, 111-113, 1986.

[2] S. Hisamatsu, Y. Takizawa, T. Abe, T. Katsumata. Fallout ${ }^{3} \mathrm{H}$ ingestion in Akita, Japan, Health Phys., Vol. 5, № № 6, 287-293, 1987.

[3] Tritium in some typical ecosystems: Technical repots series, Vienna: IAEA, No 207, 1981.

[4] De Vre Mathur, J. Binet. Molecular aspects of tritiated water and natural water in radiation biology, Progr. Biophys, and Mol. Biol., No 43, 161-193, 1984.

[5] R.M. Brown. Environmental tritium in trees, Proceedings of the Symposium on Behavior of Tritium in the Environment (16-20 Oct., 1978), San Francisco, Jointly organised by IAEA and NEA, 405-417, 1979.

[6] V.V. Dolin, O.V. Pushkarev, I.F. Shramrnko et al. Tritium in the Biosphere, Sobotovich E.V. and Dolin V.V. (Eds.), Kyiv: Naukova Dumka, 2012 (in Ukrainian).

[7] A.I. Brodskii. Chemistry of Isotopes, Moscow, AS of USSR, 1957 (In Russian).

[8] I.B. Rabinovich. Isotopy Influence on Physico-Chemical Properties of Liquids, Moscow, Nauka, 1968 (In Russian).

[9] H. Forstel. The enrichment of ${ }^{18} \mathrm{O}$ in leaf water under natural condition, Radiat. and Environ. Biophys. Vol. 15, No 4, 323-341, 1978.

[10] A. Ferhi, R. Lettolle. Transpiration and evaporation as the principle factors in oxygen isotope variation of organic matter in land plants, Physiol. Veget., Vol. 15, No 2, 363-370, 1977.

[11] V.A. Syrovatko. Tritium-containing water in plants water exchange processes, PhD Dissertation in Biology, Kyiv, 1984 (In Russian).

[12] L.F. Byelovodskyi, V.K. Gayevoi, V.I. Grishmanovskyi. 
Tritium, Moscow, Energoatimisdat, 1985 (In Russian).

[13] S.I. Levchenkov. Physical and colloid chemistry: Lecture notes, Part 2 Chemical kinetics and catalysis, Rostov-on-Don, 2004 (In Russian).

[14] D.A. Muraviova. Pharmacognosy, Moscow, Medicine, 1981 (In Russian)

[15] L.A. Lenskii. Physics and chemistry of Tritium, Moscow, Energoisdat, 1981 (In Russian).

[16] W.E. Shiegl, J.C Vogel. Deuterium content of organic matter, Earth Planet Sci. Let., No 7, 307, 1970.

[17] B.N. Smith, S. Epstein. Biochemistry of the stable isotopes of Hydrogen and Carbon in salt marsh biota, Plant Physiology, Vol. 46, 738, 1971.

[18] B.M. Andryeev, E.P. Magomedbekov, M.B. Rosenkevich, Yu.A. Sakharovskii. Heterogenic reactions of Tritium isotopic exchange, Moscow, Editorial URSS, 1999 (In Russian).

${ }^{\mathrm{i}}$ Dedicated to $100^{\text {th }}$ anniversary of National Academy of Sciences of Ukraine 